\title{
THE FEATURES OF THE DEVELOPMENT OF EDUCATION IN ELISAVETGRAD REGION IN THE SECOND HALF OF THE XIX - THE BEGINNING OF THE XX CENTURY
}

\author{
Oksana Filonenko ${ }^{1}$, Olena Vasiutynska ${ }^{2}$ \\ ${ }^{I}$ Doctor of Sciences (Pedagogy), Associate Professor, Associate Professor, Pedagogy and Management of \\ Education Department, Volodymyr Vynnychenko Central Ukrainian State Pedagogical University, \\ Kropyvnytskyi, Ukraine, e-mail: oksana.filonenko02@gmail.com, ORCID: https://orcid.org/0000-0003- \\ 4453-9887 \\ ${ }^{2}$ Post-graduate student, Pedagogy and Management of Education Department, Volodymyr Vynnychenko \\ Central Ukrainian State Pedagogical University, Kropyvnytskyi, Ukraine, e-mail: lenar@i.ua, ORCID: \\ https://orcid.org/0000-0002-3967-0269
}

Abstract. In approaches of assessing the development of Ukrainian science, it is extremely important to take into account the regional component, because there is a unique self-portrait, historical and cultural traditions, a specific cultural environment and cultural and educational space in each region of Ukraine. Elisavetgrad region is known for distinctive and original cultural and educational traditions, seminal pedagogical ideas, peculiar innovative methods and forms of their practical implementation. The purpose of the article is to study the features of the development of education in Elisavetgrad region in the second half of XIX - early XX century. The historicalstructural method gave an opportunity to arrange historical and pedagogical works on various aspects of educational development, the functions of educational institutions, distinguished persons in Elisavetgrad region in the second half of the XIX - the beginning of the XX century.

The article reveals the socio-cultural conditions of development of the region and the genesis of education in Elisavetgrad region in the second half of the XIX - the beginning of the XX century. It is established that there were a number of educational institutions from this period in the region that differed from other educational institutions in the Russian Empire by innovative approaches to the organization of the educational process: Elisavetgrad Women's Gymnasium (1860), Elisavetgrad Cavalry Junker School (1865), Elisavetgrad free craft and literacy school (1867), Elisavetgrad military grammar school (1869), Elisavetgrad high real state school (1870), Voznesensk women's grammar school (1876), Voznesensk men's grammar school (1876), Elisavetgrad men's grammar school (1879), Bobrynetsk women's grammar school (1876), Commercial school (1908), Dobrovelychkivka Women's Teacher's Seminary (1912), Novomyrhorod Women's Gymnasium (1914), etc .; a private initiative was developed in school affairs. It was found that in the second half of the XIX - the beginning of the XX century education was enriched by the achievements and creative work of public figures, educators in the Elisavetgrad region. Significant educational work was carried out by the Elisavetgrad Charitable Society for the Propagation of Literacy and Crafts (1873-1914), which was one of the most successful in the Russian Empire.

It is determined that the development of educational processes in the region was significantly influenced by socio-historical features of the country: changes in political and state system, the rise of socio-pedagogical movement, the establishment of Soviet power, the implementation of the policy of Ukrainization.

Keywords: Elisavetgrad region, region, education of Elisavetgrad region, educational institutions, professional education, innovation.

JEL Classification: I0; I20

Formulas: 0; fig.: 0; tabl.: 0; bibl.: 11.

Introduction. At the present stage of state formation, the main task of the policy of education reform is its compliance with the priorities of regional development at the regional level. One of the strategic objectives of the content of education, defined by the "National Doctrine of Education Development in Ukraine in the XXI century" 
(2002), "National Strategy for the Development of Education in Ukraine for 20122021" (2012), the Law of Ukraine "On Higher Education" (2014), "On Education" (2017), is the optimal combination of classical heritage and modern achievements of scientific thought, the use of positive achievements of national and regional pedagogical experience.

In approaches to assessing the development of Ukrainian science, it is extremely important to take into account the regional component, because each region of Ukraine has a unique self-portrait, historical and cultural traditions, a specific cultural environment and cultural and educational space. Kirovograd region (Elisavetgrad region) is known for distinctive and original cultural and educational traditions, seminal pedagogical ideas, peculiar innovative methods and forms of their practical implementation.

Literature Review. The problem of development of education and pedagogical thought in Elisavetgrad region, since the 90s of the XX century, is revealed in many works of Kirovograd researchers (P. Buldovich, V. Vdovenko, O. Guryanova, I. Dobryansky, M. Dolgikh, M Dubinka, A. Ivanko, N. Kalinichenko, J. Koloskova, V. Koretska, V. Kravtsov, V. Kudina, O. Luta, I. Mudry, I. Murovana, G. Perebyinis, O. Pertsov, V. Postolatiy, O. Prytyupa, T. Pecherytsia, L. Ryabovol, B. Khyzhnyak, I. Chernyshenko, etc.), as well as in local lore works of our compatriots (V. Biloshapka, V. Bosko, O. Chudnov, S. Shevchenko, S. Yanchukov and others).

However, the problem of scientific understanding of the peculiarities of the development of education in Elisavetgrad region in the second half of the XIX - the beginning of the XX centuries has not been the subject of a holistic study yet. At the same time, there were certain achievements in this process that have not lost their scientific and practical significance and relevance.

Aims. The purpose of the article is to study the features of the development of education in Elisavetgrad region in the second half of XIX - early XX century.

Methods. The historical-structural method gave an opportunity to arrange historical and pedagogical works on various aspects of educational development, the functions of educational institutions, distinguished persons in Elisavetgrad region in the second half of the XIX - the beginning of the XX century.

Results. There was a time of progressive changes and shifts in the 60's of the XIX century in the social life of Ukraine, as well as the Russian Empire of that time, which included the Kherson province, which affected the development of education in Elisavetgrad region. At that time the focus was on the diversity of types of educational institutions. The scope of teaching subjects and their distribution by classes in gymnasiums and real schools were determined by the curricula of the Ministry of Education. Numerous reforms of the school were aimed at improving education and adapting it to changes in society. Public education in Ukraine in the second half of the XIX - the beginning of the XX centuries, as well as in the Russian state in general, was one of the important social problems.

During this period new pedagogical ideas and concepts were born, which emerged as a result of a number of economic and educational reforms and intensified 
the social and pedagogical movement, which led to the development of education, pedagogical thought, and educational activities in Elisavetgrad educational region.

In general in the 1860s and 1890s Kherson province and Elisavetgrad region, which was a part of it, were among the largest parts in the country. Only in the county center more than 23 thousand people lived [2, p. 3].

Before the reform of 1861 in Elisavetgrad region there were only a small number of primary schools and no secondary school, from the mid-60's of the XIX century, mainly through private and public initiative, the network of primary and secondary schools began to expand in the region. Educational institutions have become key centers of life and activity of the pedagogical intelligence.

The activities of schools in Elisavetgrad district were coordinated by the Kherson zemstvo, introduced in 1865 after the approval of the "Regulations on zemstvo institutions" (1864) [1, p. 531-532]. According to the division of the Ministry of Education, it was part of the Odessa educational district. Zemstvos controlled and ensured the improvement of cities, construction of roads, water supply, etc., as well as expanded the school network. But their rights extended mainly to economic problems. The educational process was controlled by the Ministry of Education and the Synod through provincial and county school councils, principals and inspectors of public schools [7, p. 61].

According to zemstvo reports, Elisavetgrad zemstvo began to study the state of education only in the mid-60s of the XIX century, however, paid more attention to the development of the city high school for the needs of the wealthy [1, p. 463-489]. However, as we are convinced by the reports of the Zemstvo Assembly and other primary sources, this local authority made a lot of efforts not only to expand the network of primary schools in Elisavetgrad district in the second half of the XIX the beginning of the XX centuries, but also contributed to improving the educational process, supporting these educational institutions financially (the funds were allocated for the purchase of visual aids, books, etc.).

The network of secondary schools of Elisavetgrad district in the second half of the XIX - the beginning of the XX centuries formed men's and women's gymnasiums and progymnasiums, as well as one real school. Among the most significant secondary schools of Elisavetgrad district of the second half of the XIX -the beginning of the XX centuries we will name the following: Elisavetgrad women's gymnasium (1860), Elisavetgrad zemstvo real school (1870), Voznesensk women's grammar school (1876), Voznesensk men's grammar school (1876), Elisavetgrad men's grammar school (1879), Bobrynets women's grammar school (1882) (1914), Novomyrhorod Women's Gymnasium (1914), etc., which differed from other secondary schools in the Russian Empire by innovative approaches to the organization of the educational process; developed private initiative in school affairs $[9$, p. 65].

Characterizing the position of the educational sector in the county, we note that the main number of educational institutions was concentrated in Elisavetgrad. According to the data of 1861 in Elisavetgrad, in addition to the Parish County and theological school, there was an officer cavalry school, a private men's boarding 
school - Humbert, a private men's school - Speitel, 2 women's boarding schools, 3 single-class women's schools, a city women's school for children from poor families. 2 free men's Sunday schools at cavalry and county schools, state Jewish school of the I category, Jewish Talmud-tor of the first degree, 20 Jewish headers - men's and women's of the second degree [4, p. 84].

In the second half of the XIX - the beginning of the XX century there were several military educational institutions in Elisavetgrad: in 1859-1866 it was an officer cavalry school, and from 1865 to 1917 it was a cavalry school, which from 1865 to 1902 was a cadet school (ECUS) (one of the two in the whole Russian Empire), from 1902 to 1917 - the military (ECS). In 1869-1886 there was a military gymnasium (the only one on the territory of Ukraine) [8, p. 143].

One of the types of educational institutions in the Russian Empire there were real schools. Real schools at that time were considered to be secondary schools that provided real education. Elisavetgrad Zemstvo Real School is rightly considered the best educational institution in the region. From 1873 to 1882 the institution was headed by Mykhailo Romulovych Zavadsky, a teacher, educational reformer, and senator. It should be noted that it was M. Zavadsky who published from 1881 to 1883 in Elisavetgrad the first in Ukraine independent magazine from the Ministry of Public Education "Pedagogical Bulletin", which presented the advanced pedagogical ideas of that time.

Among the greatest achievements of the Elisavetgrad charity in providing the common people with both basic and special knowledge there is the rich and varied activity of the Elisavetgrad Free Crafts and Literacy School, founded on October 15, 1867 with the assistance of the teacher of the local cavalry school M. Fedorovsky and officers' wives Ryazanova and O. Nekrasova. Compared to other primary schools, this institution was much better in both educational and other aspects, and craft departments made it generally exceptional among the city or government (county) schools at that time [10, p. 14].

According to numerous documents, the Elisavetgrad Free Craft and Literacy School was the only such craft and literacy school in terms of its type, programs, and teaching skills, not only in Elisavetgrad, but also in the entire Russian Empire.

The last decade of the XIX century was marked by the rapid development of art education in the region. Elisavetgrad of the late XIX - the beginning of the $\mathrm{XX}$ centuries has the fame of the city not only with a high level of education, but also musical, artistic and theatrical culture. G. Neuhaus's music school played a significant role in the development of musical and choral culture in the city. From here the outstanding musicians and composers G. Neuhaus, F. Blumenfeld, and the classic of Polish music K. Szymanowski came out at the beginning of the XX century. The first steps in art were made by the famous artist I. Pokhitonov here, a native of the city. On October 5, 1885, the Elisavetgrad Society of Fine Arts began its activities, the members of which taught the art of singing in the premises of a noble club.

Amateur musical and theatrical groups operated on the territory of the region, which gave rise to the Ukrainian professional troupe, founded by Mark Kropyvnytsky in the autumn of 1882. M. Zankovetska, I. Karpenko-Kary, M. Sadovsky, 
P. Saksagansky, I. Tobilevich and others were also involved in this success [8, p. 35]. Prominent representatives of Ukrainian theatrical art and later folk artists of the USSR G. Yura and I. Maryanenko began their work here [11, p. 127].

At the beginning of the twentieth century there were 337 schools of various subordination and 135 church-parish schools on the territory of the region, in which about 50 thousand children studied. In addition, there were private boarding houses, Sunday and public schools, Jewish headers, and so on. These and other educational institutions played a significant role in the socio-cultural life of the region [6, p. 43].

In the beginning of the twentieth century because of the objective reasons public educational institutions had limited opportunities to innovate. Educational institutions had a much greater innovative potential, the founders of which tried to build the pedagogical process on humanistic principles, to increase its efficiency by making changes in the content, methods and forms of teaching and education. Author's educational institutions based on the original (author's) ideas and the technologies were created. That was it the Elisavetgrad Public Commercial School which was founded by the famous teacher Vasyl Ivanovych Khartsiev in 1908. It should be noted that the Elisavetgrad Public Commercial School, headed by V. Khartsyev for ten years (1909-1919), differed from other secondary schools in the Russian Empire by innovative approaches to the organization of the educational process: individual approach to students; close connection with the families of students, free choice of methods of teaching and education by teachers. The educational process of the commercial school was built on democratic, humanistic, pedocentric, labor (active) principles, which contributed to the purposeful, comprehensive and harmonious development of students.

In the beginning of the twentieth century along with the problem of providing educational services for the population, the urgent issue was the implementation of in-service teacher training to increase the number of professionally trained teachers, as well as in-service training of existing ones. From 1909 they became two-year, later - three-year training [9, p. 168].

It is worth to note that in the territory of our region at the Dolynska station of the Southern Railway of the Kherson province the outstanding teacher Anton Semenovich Makarenko began his pedagogical activity, working in a two-class railway school (1911-1913).

In the beginning of the 1920's, after the final establishment of Soviet power in Ukraine, state $\mathrm{p}$ restructuring began, in the process of which a number of educational reforms were carried out. The reform was carried out in difficult socio-economic, socio-political conditions. The most important feature of school education in the region at that time was its subordination to the interests of the state, the restructuring of public life.

Peculiarities of the studied period (the need to rebuild and build new educational institutions, etc.) led to the fact that school education in the region developed in difficult financial conditions, it forced to use funds from residents and rural communities to support schools in the 1920s. There was a shortage of qualified teachers in the region. 
The functioning of school education at that time was assessed by statistics: the number of schools, the number of students, the number of teachers; the number of Ukrainian schools and the schools of national minorities, the education of children of workers, peasants, artisans, etc. In 1920, there were 500 schools in the region, including 28 schools in Elisavetgrad. There were 494 schools in the county. There was a network of "elimination of illiteracy" (651), schools for adults (77), orphanages (21), and vocational schools (19) [6, p. 44].

Beginning from 1923 the financial situation of the region's socialist institutions gradually increased, the teachers' salaries increased, and the percentage of children enrolled in school increased. Thus, in the Zinoviev district in 1924/1925 AD there were 493 schools; between them I degree (1-4 classes) - 469, II degree (5-7 classes) - 34. They were distributed as follows: in the District city -17 , freelance cities -22 , in rural areas -454 . In general, $36.5 \%$ of the district's children were covered by the socialist education schools. In 1925/1926 academic year $47.08 \%$ - the number of children which was covered by the school from the total number of school-age children [3, p. 465-566].

Note that the sources of funding for schools were diverse. After the decree of July 13, 1922, labor schools were removed from the state budget and transferred to local maintenance. The contractual campaign (maintenance of schools by the population) did not yield noticeable results, and the gradual strengthening of the budget allowed, according to archival documents, within the old district for 1924/1925 to open 12 such schools in 5 districts of the region [3, p. 560].

The economic needs of schools (upkeep) were provided by village councils and village societies. More than $50 \%$ of schools provided textbooks to students at the expense of parents. Salaries of teachers in these schools, as well as contributions to socialist education were made at the expense of parents or the population in the amount of local budget rates.

These facts allow us to conclude that the creation of contract schools, attracting funds from the population was not caused by strict requirements of the authorities, and the difficult situation and the need to rebuild schools. It should be noted that these processes did not take place spontaneously, but in accordance with the decisions of the provincial congresses and meetings on public education.

The public involvement in education management is becoming widespread in the region. The activity of regional educational structures is a vivid example of the policy of decentralization of management. But both decentralization and selfgovernment had clear limitations and had to ensure the implementation of state guidelines. The freedom of methodical searches of pedagogical workers had a similar character.

Gradually, a clear system of methodological work is being formed in the region. Methodical commissions existed on funds that were deducted from the special funds of labor schools and educational institutions. Labor schools were taken as bases in the districts. There were no bases on the Professional Education Vertical, as well as on the Political World, except one elimination of illiteracy school. Due to the lack of funds all research supporting shools were in very difficult financial conditions. 
From the first half of the twentieth century attention was paid not only to primary and secondary education in the region, but also to the training of qualified specialists in the field of public education. This was due to the dynamic reform of the education system, the lack of educational staff and the inconsistency of working teachers with modern requirements.

Thus, in the 20's. XX century pedagogical courses were the most widespread form of teacher training. In 1922 the Elisavetgrad Higher Pedagogical Courses with a three-year term of study began to operate. In a number of documents, these courses are called universities. The tuition was paid. In 1923-1925 the Elisavetgrad Higher Pedagogical Courses were headed by a professor Vasyl Ivanovych Khartsiev [5, p. 55-59].

Note that the 20s of the twentieth century also differed from all other periods by the general spread of methodical work, the development of the system of advanced training, the holding of pedagogical meetings and congresses. Thus, in some years the training of all teachers was carried out. This was due to the fundamentally new nature of the tasks and technologies of school work and the lack of a sufficient number of qualified teachers. The development of the system of pedagogical education allowed to solve the problem of providing the school with teachers at the end of the period.

Discussion. Reforming school education at that period was provided for a policy of Ukrainization. Archival materials show that painstaking work was carried out in the case of Ukrainization in our region. Thus, in the conclusions of the survey of the District Commission on Ukrainization which was conducted on November 11, 1926 by the inspector of the District Executive Committee O. Dudarenko it is noted that "in the case of Ukrainization both in the district and throughout the district instructional materials were provided in full to institutions and government commissions. Carrying out Ukrainization did not violate the rights and interests of national minorities "[3, p. 515].

Thus, in general, this period was a controversial and important stage in the development of education in the region. The main reasons for the reform of school education were primarily political: a change in the political system, and pedagogical - the needs of school practice. It was found that the 20 s of the twentieth century are characterized by the following areas of educational development in the region: the general spread of methodological work, the development of advanced training, the pedagogical meetings and congresses. The most important feature of education in the region at that time was its subordination to the interests of the state, the restructuring of public life.

Conclusions. It was found out that from the second half of the XIX century, mainly due to private and public initiative, the network of primary and secondary schools began to expand in the region, which differed in innovative approaches to the organization of the educational process; a private initiative developed in school affairs.

During the analysis of socio-cultural conditions of education development in the region in the second half of the XIX - first third of the XX century it was established that the development of educational processes in the region was significantly 
influenced by the socio-historical features of the country: changes in the political and state system, the rise of the socio-pedagogical movement, the establishment of Soviet power, the policy of Ukrainization.

The prospects for further exploration are the history of primary, secondary and higher education in the region, the theory and practice of education.

Author contributions. The authors contributed equally.

Disclosure statement. The authors do not have any conflict of interest. References:

1. Borisov Ye. I. Sistematicheskiy svod postanovleniy Elisavetgradskogo uyezdnogo zemskogo sobraniya za 1865-1895 gg. [A systematic code of resolutions of the Elisavetgrad district council for 1865-1895]. Elisavetgrad: Tip. Gol'denberga, 1895. 897 s.

2. Zhurnaly zasedaniy Elisavetgradskogo uyezdnogo zemskogo sobraniya XLI ocherednoy sessii 1905 g. [Meeting logs of the Elisavetgrad district council meeting of the XLI regular session of 1905]. Elisavetgrad, 1905. S. 3.

3. Inspektura narodnoyi osvity Zinov'yevs'koho okruzhnoho vykonavchoho komitetu rady robitnychykh, selyans'kykh i chervonoarmiys'kykh deputativ, m. Zinov'yevs'k Zinov'yevs'koho okruhu [People's Education Inspectorate of the Zinovievsky District Executive Committee of the Workers', Peasants' and Red Army Deputies' Council, Zinovievsk Zinovievsky District]. Derzhavnyy arkhiv Kirovohrads'koyi oblasti. F. 810. Spr. 2078. 560 ark.

4. Istoriya mist i sil Ukrayins'koyi RSR. Kirovohrads'ka oblast' [History of cities and villages of the Ukrainian SSR]. Kirovograd region. K. : Holovna redaktsiya URE AN URSR, 1972. 816 s.

5. Kalinichenko N. A. Vasyl' Khartsiyev: pidhotovka pedahohichnykh kadriv [Vasil Khartsiev: training of pedagogical personnel]. Istoryko-pedahohichnyy al'manakh. 2012. № 2. S. 55-59.

6. Kuzyk B. M., Biloshapka V. V. Kirovohradshchyna: istoriya ta suchasnist' tsentru Ukrayiny [Kirovograd region: the history and the present of the center of Ukraine]. D.: v 2 t. ART-PRES, 2005. T. 1. $496 \mathrm{~s}$.

7. Lytvynov I. D. Narys osnovnykh napryamkiv narodnohospodars'koho rozvytku Kirovohrads'koyi oblasti [Essay on the main directions of economic development of the Kirovograd region]. Naukovi zapysky Kirovohrads'koho pedahohichnoho instytutu im. O. S. Pushkina. Kirovohrad, 1958. Vyp. 6. S. 39-75.

8 Pertsov O. V. Rozvytok viys'kovoyi osvity na Yelysavethradshchyni (druha polovyna XIX - pochatok XX stolittya) [Development of military education in Yelisavetchrad region (second half of XIX - beginning of XX century)]. Dys. ... kand. ped. nauk: 13.00.01. Kirovohrad, 2016. 254 s.

9. Prytyupa O.S. Krayeznavchi zasady rozvytku pryrodnychoyi osvity na Yelysavethradshchyni (druha polovyna XIX - pochatok XX stolittya) [Local studies on the development of natural science education in Yelisavetchrad region (second half of the XIXth - the beginning of the twentieth century)]. Dys. ... kand. ped. nauk: 13.00.01. Kirovohrad, 2013. 235 s.

10. Ryabkov P. Z. Kratkiy istoricheskiy ocherk Elisavetgradskogo Obshchestva rasprostraneniya gramotnosti i remesel: 1873-1898 gg. [A brief historical essay on the Elisavetgrad Society for the Promotion of Literacy and Crafts: 1873-1898]. Elisavetgrad: Tip. Gol'denberga, 1898. 42 s.

11. Filoretova L. M. Yelysavethrads'ka hromada [The Elisavetgrad community]. Naukovyy chasopys NPU im. Drahomanova. Seriya 6: istorychni nauky. K., 2011. Vyp. 9. S. 123-130. 